\title{
Electron Transfer Mediators for Photoelectrochemical Cells Based on Cu(I) Metal Complexes
}

\author{
Michele Brugnati, Stefano Caramori, Silvia Cazzanti, Luca Marchini, \\ Roberto Argazzi, and Carlo A. Bignozzi \\ Dipartimento di Chimica, dell'Università di Ferrara, CNR-ISOF, Via Luigi Borsari 46, 44100 Ferrara, Italy
}

Received 30 May 2007; Accepted 1 November 2007

Recommended by Nicolas Alonso-Vante

The preparation and the photoelectrochemical characterization of a series of bipyridine and pyridyl-quinoline $\mathrm{Cu}(\mathrm{I}) \mathrm{complexes}$, used as electron transfer mediators in regenerative photoelectrochemical cells, are reported. The best performing mediators produced maximum IPCEs of the order of 35-40\%. The J-V curves recorded under monochromatic light showed that the selected $\mathrm{Cu}(\mathrm{I}) /(\mathrm{II})$ couples generated higher Vocs and fill factors compared to an equivalent $\mathrm{I}^{-} / \mathrm{I}_{3}{ }^{-}$cell, due to a decreased dark current.

Copyright (c) 2007 Michele Brugnati et al. This is an open access article distributed under the Creative Commons Attribution License, which permits unrestricted use, distribution, and reproduction in any medium, provided the original work is properly cited.

\section{INTRODUCTION}

Graetzel-type photoelectrochemical cells-based on wideband-gap semiconductors have attracted the scientific attention of many research groups due to their potential for direct sunlight-to-electricity conversion $[1,2]$. These cells are basically biphasic systems consisting of a sensitized mesoporous semiconducting metal oxide $\left(\mathrm{TiO}_{2}, \mathrm{SnO}_{2}, \mathrm{ZnO}\right.$, etc. $)$ in contact with an electrolyte which permeates the pores between the interconnected nanoparticles. Indeed, the basic event is the photoinduced electron transfer from the excited state of the sensitizer to the conduction band of the semiconductor which acts as an electron collector. The photooxidized dye created in this process is subsequently restored by a redox couple (electron mediator) dissolved in the electrolyte. While the porous nature of the semiconductor greatly improves the surface area, leading to efficient visible light harvesting by the sensitizer, the small size of the nanoparticles is not able to sustain a relevant electric field [3, 4]. Therefore, to avoid significant losses due to electronic recombination with acceptor states of the electrolyte, the electron mediator has to be chosen carefully. The iodide-iodine system has been by far the most popular redox couple for this type of applications. Reduction of iodine is a slow process which allows for the minimization of electronic recombination at the semiconductor-electrolyte interface; at the same time, reduction of the oxidized sensitizer by iodide is a fast process which occurs in the nanosecond-sub-microsecond time scale $[5,6]$.
As a consequence, an efficient interfacial charge separation, where the electron is confined in the semiconductor and the hole is confined in the liquid phase can be achieved mainly by virtue of the kinetic properties of the mediator. Obviously, in order to avoid accumulation of iodine, its reduction at the counter electrode of the cell has to be catalyzed by the presence of metallic Pt. Unfortunately along with nearly ideal kinetic properties, the $\mathrm{I}^{-} / \mathrm{I}_{3}{ }^{-}$couple possesses a list of undesirable characteristics: its corrosivity [7] and volatility have been a limiting factor to dye sensitized solar cells (DSSC) development and diffusion; quite surprisingly, some studies have pointed out that even platinum itself can be attacked on long time scales [8]. Moreover, the $\mathrm{I}^{-} / \mathrm{I}_{3}{ }^{-}$thermodynamic potential is less than ideal for its use in conjunction with a large number of sensitizers. For all these reasons, the study of new electron mediators potentially capable of replacing the iodide/iodine couple is attractive for at least two reasons: first, the investigation of new redox systems may improve our knowledge of the basic charge separation events and their dependence from the inherent structural and electrochemical properties of new mediators; second, the discovery of new efficient non corrosive electron mediators may boost DSSC as a convenient renewable energy source.

As explained above, a sluggish electron recapture on semiconductor oxide surfaces is believed to be crucial for the correct operation of the mediator. To our knowledge, there is no certain a priori indication that such requirement would be fulfilled by a given chemical species; however, in 
principle, every system characterized by a high reorganization energy associated to the electron transfer should exhibit a slow kinetic. This has been proved by previous studies on Co(II) complexes carried out by the Graetzel group and by our group $[9,10]$. $\mathrm{Cu}(\mathrm{I}) /(\mathrm{II})$ coordination compounds might also result attractive due to the relevant nuclear rearrangement that should occur when tetrahedral $\mathrm{Cu}(\mathrm{I})$ complexes are oxidized to octahedral or trigonal-bipyramidal $[11,12]$ $\mathrm{Cu}$ (II) species and vice-versa.

In this study, we report the preparation and the photoelectrochemical characterization of a series of $\mathrm{Cu}(\mathrm{I})$ complexes, based on substituted bipyridine and quinoline derivatives, used as electron transfer mediators in sandwich type DSSCs. To stabilize the $\mathrm{Cu}(\mathrm{I})$ oxidation state of $\mathrm{Cu}(\mathrm{I})$ polypyridine complexes, electron withdrawing substituents like esters have been considered. The same effect was obtained also with pyridil-quinoline and biquinoline complexes, thanks to the increased $\pi$ accepting properties of the quinoline condensed aromatic rings.

\section{EXPERIMENTAL}

Materials. 2-nitrobenzaldehyde, 2-acetyl-pyridine, 4-tert-butyl-pyridine, 2-nitro-acetophenone, biquinoline, trimethylsilyl cyanide, dimethyl-carbamyl-chloride, iodomethane, hydrogen peroxide, magnesium sulphate, magnesium shavings, tin granules, copper powder, $\mathrm{Cu}\left(\mathrm{ClO}_{4}\right)_{2} \times 6 \mathrm{H}_{2} \mathrm{O}$, iron (II) ammonium sulphate, $\mathrm{NH}_{4} \mathrm{Cl}, \mathrm{Na}_{2} \mathrm{CO}_{3}, \mathrm{SOCl}_{2}$, normalbutanol were purchased from Aldrich and used without further purifications. Analytical grade tert-butanol (Fluka Milano, Italy) was dried over molecular sieves ( $3 \AA$ ) before use. Other analytical grade solvents, concentrated ammonium hydroxide and glacial acetic acid were from Fluka, Carlo Erba, and Fisher and used as received, unless otherwise stated.

$4,4^{\prime}$ dimethyl-2,2' bipyridine was prepared by catalytic dehydrogenation of freshly distilled 4-picoline (Aldrich) in presence of $10 \% \operatorname{Pd}(\mathrm{C})$ (Fluka) [13].

$2,2^{\prime}$-bipyridine- $4,4^{\prime}$-di-carboxylic acid $\left(\mathrm{H}_{2} \mathrm{DCB}\right)$ was prepared by oxidation of $4,4^{\prime}$-dimethyl-2, $2^{\prime}$-bipyridine with chromic acid according to a previously reported procedure [14]. 2,2'-bypiridine-di-4,4' -ethyl ester (bpy-(COOEt) $)_{2}$ ) (1) was prepared following literature methods [15]. 2,2' -pyridilquinoline (PQ) (4) was synthesized following a previously reported Friedlander condensation [16].

Titanium isopropoxide ( $\left.\mathrm{Ti}(\mathrm{ip})_{4}\right)$ 98\%, $\mathrm{TiCl}_{4}$ 98\%, and absolute ethanol were obtained from Fluka and used as received.

The ruthenium sensitizer $\left[\mathrm{Ru}(\mathrm{dnbpy})\left(\mathrm{H}_{2} \mathrm{DCB}\right)(\mathrm{NCS})_{2}\right]$ ( $Z$ 907), where (dnbpy) is the $4,4^{\prime}$ dinonyl-2,2' -bipyridine, was prepared according to literature procedures [17].

Conductive FTO glasses, ca. $8 \mathrm{Ohm} / \square$, were from Pilkington (Merseyside UK). Prior to electrochemical measurements conductive glass pieces $\left(\mathrm{ca} .0 .5 \mathrm{~cm}^{2}\right.$ ) were carefully cleaned by subsequent repeated soakings and sonications in saturated $\mathrm{KOH} /$ isopropanol, deionized water and acetonitrile.

Spectroscopic grade acetonitrile (ACN) (Fluka) was used for photoelectrochemical and electrochemical measure- ments. $\mathrm{LiClO}_{4}$ (Aldrich) was generally employed as a supporting electrolyte.

Analytical measurements. ${ }^{1} \mathrm{H}$ NMR and ${ }^{13} \mathrm{C}$ spectra were recorded either on a Varian Gemini $300 \mathrm{MHz}$ spectrometer or on a Bruker $200 \mathrm{MHz}$ spectrometer.

ESI mass spectra were collected with a Waters Micromass ZMD-2000 spectrometer.

Elemental Analysis was carried out with a Carlo Erba CE 110 Elemental Analyzer.

Photoaction spectra were obtained with a custom made apparatus comprising a water cooled Xe lamp (Osram XBO, $150 \mathrm{~W}$ ) coupled to an applied photophysics monochromator, adopting a $10 \mathrm{~nm}$ spectral bandwidth. Illuminated cell area was $0.5 \mathrm{~cm}^{2}$. Photocurrents, sampled at $20 \mathrm{~nm}$ intervals, were recorded under short circuit conditions using an Agilent 34401A digital multimeter. Incident irradiances were measured by means of a Centronic OSD100-7Q calibrated silicon photodiode and the incident photon-to-electron conversion efficiency (IPCE) was calculated according to the formula

$$
\operatorname{IPCE} \%=1240 \frac{\mathrm{J}}{\lambda \mathrm{W}}
$$

where $\mathrm{J}$ is the photocurrent density expressed in $\mu \mathrm{A} / \mathrm{cm}^{2}, \lambda$ is the wavelength of incident monochromatic light, and $\mathrm{W}$ is the radiant power in $\mathrm{W} / \mathrm{m}^{2}$.

J-V curves obtained under $510 \mathrm{~nm}$ monochromatic light were collected with an Amel model 562 Potentiostat, using the same apparatus described above, by varying the applied potential between 0 and $-550 \mathrm{mV}$ adopting a two-electrode configuration. In all cases irradiation was through the photoanode.

Electrochemical measurements (CV and LSV) were carried out in a three electrode arrangement with an Ecochemie Autolab PGSTAT 30 electrochemical workstation.

Photoanode preparation. In order to avoid incidental electronic recombination from the FTO back contact, a compact $\mathrm{TiO}_{2}$ underlayer was created prior to porous $\mathrm{TiO}_{2}$ deposition: typically $\approx 200 \mu \mathrm{L}$ of freshly prepared precursor solution $\left(0.2 \mathrm{M} \mathrm{Ti}(\mathrm{ip})_{4}\right.$ in absolute ethanol), was spin coated onto cleaned FTO substrates $(2 \times 2.5 \mathrm{~cm})$ at $2000 \mathrm{rpm}$ for about 30 seconds. The resulting layer was baked at $450^{\circ} \mathrm{C}$ for $30 \mathrm{~min}-$ utes, resulting in a transparent compact $2 \mathrm{~cm}^{2} \mathrm{TiO}_{2}$ film.

Mesoporous $\mathrm{TiO}_{2}$ films were obtained by casting over the compact $\mathrm{TiO}_{2}$ underlayer a colloidal $\mathrm{TiO}_{2}$ paste [18] using the well-known adhesive tape casting method. The resulting film $\left(2 \times 0.5 \mathrm{~cm}^{2}\right)$ was sintered in an oven at $450^{\circ} \mathrm{C}$ for 40-45 minutes. The final step involved the application of an aqueous $2 \mathrm{M} \mathrm{TiCl}_{4}$ solution onto the mesoporous $\mathrm{TiO}_{2}$ substrate, as it has been generally recognized that such treatment improves the photoelectrochemical properties of the DSSC [19].

Sensitization was carried out by immersion of the $\mathrm{TiO}_{2}$ photoelectrodes in a ca. $10^{-5} \mathrm{M}$ sensitizer solution in absolute ethanol. This procedure was carried out in the dark either at refluxing temperature for 3-4 hours or at room temperature for approximately 12 hours. After this time, dye adsorption on $\mathrm{TiO}_{2}$ was complete, leading to red-colored 


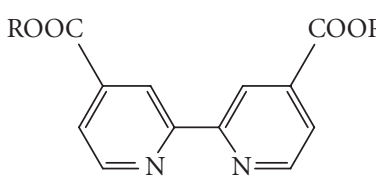

$\mathrm{R}=$ Ethyl (1), n-butyl (2)

Tert-butyl (3)

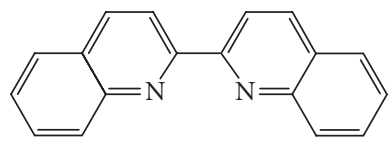

6

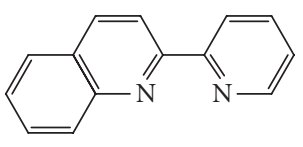

4

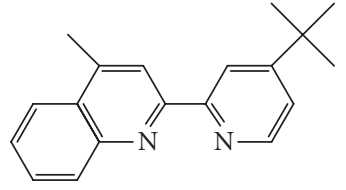

5

Figure 1: Structures of the ligands employed for the preparation of $\mathrm{Cu}(\mathrm{I})$ complexes: $2,2^{\prime}$-bypiridine di-4,4' ${ }^{\prime}$-ethyl ester (bpy-(COOEt) $\left.)_{2}\right)(\mathbf{1})$, 2,2' -bypiridine-di-4,4' -n-butyl ester (bpy-(COOnBut) 2 (2), 2,2' -bypiridine-di-4,4' -Tert-butyl ester (bpy-(COOTbut) 2 ) (3), 2,2' -pyiridylquinoline (PQ) (4), 4-methyl,4' -Tert-butyl-2,2' pyridil-quinoline (MeTbPQ) (5), 2,2' biquinoline (BQ) (6).

photoelectrodes characterized by a maximum absorbance $>1$ in the 500-550 $\mathrm{nm}$ region.

Counter electrode preparation. Gold or silver coated counter electrodes (ca. $100 \mathrm{~nm}$ ) were obtained by thermal vapour deposition of gold onto well-cleaned FTO glass pieces $(2.5 \times 2 \mathrm{~cm})$ using a custom built thermal evaporator (ISTA, Faenza, Italy). The average pressure in the evaporation chamber was of the order of $9 \times 10^{-6}$ torr. Pt coated counter electrodes were prepared by repeated spraying of a $5 \times 10^{-3} \mathrm{M}$ $\mathrm{H}_{2} \mathrm{PtCl}_{6}$ solution in isopropanol onto cleaned FTO glass pieces $(2.5 \times 2 \mathrm{~cm})$. Pyrolysis of the resulting substrates at $380^{\circ} \mathrm{C}$ for 15 minutes led to the formation of stable dark Pt clusters on the FTO surface.

Solar cell assembly. Sandwich-type photoelectrochemical cells were assembled by clamping the photoactive electrode over the gold coated counter electrode. A parafilm gasket (ca. $120 \mu \mathrm{m}$ thick) was used to avoid the direct contact between the two electrodes and to confine the electrolytic solution inside the cell. The relay consisted of a $0.15 \mathrm{M}$ solution of the desired $\mathrm{Cu}(\mathrm{I})$ complex in acetonitrile. A portion of it, typically $1 / 10$, was oxidized to $\mathrm{Cu}$ (II) by addition of a stoichiometric amount of $\mathrm{NOBF}_{4} \cdot \mathrm{Li}^{+} 0.5 \mathrm{M}$ was added to all copper based electrolytic mixtures. The performances of the new mediators were compared to a classical LiI/ $\mathrm{I}_{2}$ 0.5/0.05 M electrolyte. In case of iodide/iodine mixtures, a Pt sputtered counter electrode was used.

Thin-layer electrochemical cell. To gain some kinetic information about the electrochemical behavior of selected copper complexes, a cofacial three-electrode thin-layer electrochemical cell was assembled. The surface of an FTO glass was mechanically (by scoring the FTO surface with a carborundum tip) or electrochemically etched in order to obtain an insulating gap between the two halves of the same electrode, among which a resistance $>50 \mathrm{M} \Omega$ was measured. One half was coated with gold and served as the working electrode (WE, $1 \mathrm{~cm}^{2}$ geometrical area), the other was coated with silver and served as the quasireference electrode (QRE). The WE+QRE electrode was cofacially assembled with a gold coated counter electrode (CE), using a parafilm frame $(\mathrm{ca} .120 \mu \mathrm{m})$ as a spacer. Each electrode was appropriately connected to the potentiostat leads via copper stripes protected and sealed with Surlyn, in order to avoid accidental contacts between them and the electrolyte. Few drops of electrolyte consisting of $0.1 \mathrm{M} \mathrm{LiClO}_{4}$ and $5 \times 10^{-4} \mathrm{M}$ $\mathrm{Cu}(\mathrm{I}) / \mathrm{Cu}(\mathrm{II})$ in $\mathrm{ACN}$ were injected in the cell and the measurements performed.

Ligand preparation. Bypiridine and quinoline derivatives used for this study are shown in Figure 1.

2,2'-bypiridine-di-4,4'-n-butyl ester (bpy-(COOnBut $\left.)_{2}\right)$ (2). A solution of 2,2'-bipyridyl-4,4'-dicarboxylic acid ( $850 \mathrm{mg}, 3.48 \mathrm{mmol})$, concentrated sulfuric acid $(1 \mathrm{~mL})$ and normal-butanol $(40 \mathrm{~mL})$, was heated at reflux for 3 days. After this time, the reaction mixture was cooled to room temperature and concentrated to few milliliters under reduced pressure. The liquid residue was neutralized by addition of aqueous $\mathrm{Na}_{2} \mathrm{CO}_{3}$ and a yellowish solid separated. Subsequent chromatographic separation of the precipitate (Silica Gel 60/ethyl acetate) afforded the pure product as white waxy solid: ${ }^{1} \mathrm{H}$ NMR $\left(200 \mathrm{MHz}, \mathrm{CDCl}_{3}, \delta \mathrm{ppm}\right): 9.00(\mathrm{~s}, 2 \mathrm{H})$; $8.85(\mathrm{dd}, 2 \mathrm{H}) ; 7.90(\mathrm{dd}, 2 \mathrm{H}) ; 4.40(\mathrm{t}, 4 \mathrm{H}) ; 1.70(\mathrm{~m}, 4 \mathrm{H}) ; 1.50$ $(\mathrm{m}, 4 \mathrm{H}) ; 1.00(\mathrm{t}, 6 \mathrm{H})$.

2,2' - bypiridine-di-4,4' -tert-butyl ester (bpy- $\left.(\mathrm{COOTbut})_{2}\right)$ (3). $1 \mathrm{~g}$ of $\mathrm{H}_{2} \mathrm{DCB}$ was suspended in $100 \mathrm{~mL}$ of $\mathrm{SOCl}_{2}$ and refluxed under nitrogen for several hours to obtain the corresponding di-acylchloride. The reaction was deemed complete when the solid was totally dissolved, leading to a perfectly transparent pale yellow solution. The excess $\mathrm{SOCl}_{2}$ was removed by rotary evaporation and the solid residue was immediately reacted with an excess of sodium tert-butoxide (obtained by reaction of metallic $\mathrm{Na}$ with anhydrous tertbutanol) in tert-butanol. The resulting yellowish slurry was stirred for a few hours under gentle heating, treated with an excess of aqueous $\mathrm{NaHCO}_{3}$ and repeatedly extracted with $\mathrm{CH}_{2} \mathrm{Cl}_{2}$. The organic phase was collected, dried over $\mathrm{Na}_{2} \mathrm{SO}_{4}$, and rotary evaporated to dryness, affording the desired compound as a white waxy solid: ${ }^{1} \mathrm{H} \mathrm{NMR}\left(300 \mathrm{MHz}, \mathrm{CDCl}_{3}\right.$, 
$\delta \mathrm{ppm}): 8.8(\mathrm{~m}, 4 \mathrm{H}) ; 7.85(\mathrm{~m}, 2 \mathrm{H}) ; 1.6(\mathrm{~s}, 18 \mathrm{H}),{ }^{13} \mathrm{C} \mathrm{NMR}$ $\left(300 \mathrm{MHz}, \mathrm{CDCl}_{3}, \delta \mathrm{ppm}\right): 164.21 ; 156.53 ; 149.94 ; 140.53$; $123.14 ; 120.55 ; 28.09$.

4-tert-butyl-pyridil-N-oxide. $14.64 \mathrm{~mL}$ of 4 Tert-butyl pyridine were dissolved in $66.7 \mathrm{~mL}$ of glacial acetic acid. $10.3 \mathrm{~mL}$ of $30 \% \mathrm{v} / \mathrm{v} \mathrm{H}_{2} \mathrm{O}_{2}$ were then added and the resulting mixture was refluxed for 24 hours. Solvents were removed by rotary evaporation and yellow viscous oil was obtained. The residue was diluted with water and neutralized with $20 \mathrm{w} / \mathrm{v} \mathrm{NaOH}$. The aqueous solution was extracted with dichloromethane $(2 \times 40 \mathrm{~mL})$. The organic layer was collected and dried over $\mathrm{Na}_{2} \mathrm{SO}_{4}$. After evaporation of the solvent under reduced pressure, a pale yellow oil was obtained. The liquid solidified after 2 days at $4^{\circ} \mathrm{C}$. The purity of the product was confirmed by TLC (silica gel, AcOEt-MeOH 9-1, $\mathrm{NH}_{3}$ ) and NMR: ${ }^{1} \mathrm{H}$ NMR (300 $\left.\mathrm{MHz}^{\mathrm{CDCl}}{ }_{3} \delta \mathrm{ppm}\right): 8.1(\mathrm{~d}, 2 \mathrm{H})$; $7.2(\mathrm{~d}, 2 \mathrm{H}) 1.2(\mathrm{~s}, 9 \mathrm{H})$.

4-tert-butyl-2-cyano-pyridine. To a solution made of $6 \mathrm{~g}(0.0398 \mathrm{~mol})$ of 4 -tert-butyl-pyridyl-N-oxide and of $5 \mathrm{~g}$ $(0.0504 \mathrm{~mol})$ of trimethyl-silyl-cyanide in anhydrous dichloromethane were added, over a 30-minute period, $4.64 \mathrm{~mL}$ of dimethyl-carbamyl-chloride, dissolved in $10 \mathrm{~mL}$ of anhydrous $\mathrm{CH}_{2} \mathrm{Cl}_{2}$. The resulting reaction mixture was left under stirring at room temperature for 36 hours, during which the color of the solution turned from pale yellow to brownish. A $10 \% \mathrm{Na}_{2} \mathrm{CO}_{3}$ solution was slowly added by means of an addition funnel. The two phases were allowed to separate and the organic layer was collected. The aqueous phase was extracted twice with $25 \mathrm{~mL}$ of $\mathrm{CH}_{2} \mathrm{Cl}_{2}$. The combined organic extracts were dried over sodium sulphate and the solvent evaporated under reduced pressure. Yellow oil was obtained: ${ }^{1} \mathrm{H} \mathrm{NMR}\left(300 \mathrm{MHz}^{-C_{C l}} \delta \mathrm{ppm}\right): 8.6(\mathrm{~d}, 1 \mathrm{H}) ; 7.7(\mathrm{~d}, 1 \mathrm{H})$; 7.5 (dd,1H); $1.3(\mathrm{~s}, 9 \mathrm{H})$.

4-tert-butyl-2-acetyl-pyridine. To the Grignard reagent $\mathrm{CH}_{3} \mathrm{MgI}$, obtained by reaction of $2.67 \mathrm{~g}$ of $\mathrm{Mg}$ shavings with $6.89 \mathrm{~mL}$ of $\mathrm{CH}_{3} \mathrm{I}$ in anhydrous diethyl ether, $6.85 \mathrm{~g}$ of 4 -Tertbutyl-2-cyano pyridine, dissolved in $70 \mathrm{~mL}$ of anhydrous diethyl ether, were added. The resulting mixture was left under stirring at room temperature for 3 hours, after which the reaction was quenched with saturated aqueous $\mathrm{NH}_{4} \mathrm{Cl}$. The two phases separated and the organic layer was collected. The aqueous layer was further extracted with ethyl acetate $(2 \times 30 \mathrm{~mL})$ and the resulting combined organic extracts were subsequently washed with water $(3 \times 30 \mathrm{~mL})$, with $10 \mathrm{~mL}$ of a concentrated $\mathrm{NaCl}$ solution and dried over magnesium sulphate. The solvents were removed under reduced pressure and the residue (a viscous oil) was purified by column chromatography (silica gel $60, \mathrm{CH}_{2} \mathrm{Cl}_{2}$ ). $2 \mathrm{~g}$ of pure product were obtained: ${ }^{1} \mathrm{H}$ NMR (300 MHz $\mathrm{CDCl}_{3} \delta$ ppm): $8.6(\mathrm{~d}, 1 \mathrm{H}) ; 8.1$ $(\mathrm{d}, 1 \mathrm{H}) ; 7.5(\mathrm{dd}, 1 \mathrm{H}) ; 2.73(\mathrm{~s}, 3 \mathrm{H}) ; 1.35(\mathrm{~s}, 9 \mathrm{H})$.

2-amino-acetophenone. $2 \mathrm{~g}$ of 2 -nitro-acetophenone were suspended in $30 \mathrm{~mL}$ of water, $4.26 \mathrm{~g}$ of tin granules, and $10.3 \mathrm{~mL}$ of concentrated $\mathrm{HCl}$ were then added and the resulting mixture was refluxed for 2 hours. After this time the reaction mixture was cooled at room temperature, filtered from undissolved tin granules and neutralized with $33 \% \mathrm{NaOH}$. Precipitated $\mathrm{Sn}(\mathrm{OH})_{2}$ was removed by filtration. The aqueous filtrate was collected and extracted with diethylether $(3 \times 30 \mathrm{~mL})$. The combined organic extracts were collected, washed with water $(2 \times 30 \mathrm{~mL})$, and dried over sodium sulphate. The solvent was removed under reduced pressure and yellow oil corresponding to the desired product was finally obtained: IR in $\mathrm{KBr}$ pellet: $3463,3341 \mathrm{~cm}^{-1}$ $\left(\mathrm{NH}_{2}\right) ; 1644 \mathrm{~cm}^{-1}(\mathrm{C}=\mathrm{O})$.

4-methyl, $4^{\prime}$-tert-butyl-2,2' pyridil-quinoline (MeTbPQ) (5): $0.683 \mathrm{~g}$ of 2-acetyl-4-tertbutyl-pyridine and $0.52 \mathrm{~g}$ of 2-amino-acetophenone were dissolved in $20 \mathrm{~mL}$ of ethanol. $7 \mathrm{~mL}$ of $1 \mathrm{M} \mathrm{KOH}$ were added and the resulting mixture was refluxed 12 hours. The reaction mixture was poured in $100 \mathrm{~mL}$ of water (the formation of colloidal precipitate was observed), the $\mathrm{pH}$ was adjusted to neutrality with $\mathrm{HCl}$ and the solvents were removed under reduced pressure. The residue was dissolved in $\mathrm{CH}_{2} \mathrm{Cl}_{2}$, while the insoluble salt $(\mathrm{KCl})$ was removed by filtration. The product was purified by column chromatography (silica gel 60 , AcOEt/ $\mathrm{CH}_{2} \mathrm{Cl}_{2}$ 1/9). $0.5 \mathrm{~g}$ of yellowish oil corresponding to the desired product (5) was obtained. The oil solidified at $4^{\circ} \mathrm{C}$ after several days to give pale yellow solid: ${ }^{1} \mathrm{H}$ NMR $(300 \mathrm{MHz}$, $\left.\mathrm{CDCl}_{3} \delta \mathrm{ppm}\right): 8.65(\mathrm{~d}, 2 \mathrm{H}) ; 8.4(\mathrm{~s}, 1 \mathrm{H}) ; 8.2(\mathrm{~d}, 1 \mathrm{H}) ; 8(\mathrm{~d}, 1 \mathrm{H})$, $7.7(\mathrm{~m}, 1 \mathrm{H}) ; 7.55(\mathrm{~m}, 1 \mathrm{H}) ; 7.18(\mathrm{dd}, 1 \mathrm{H}) ; 2.8(\mathrm{~s}, 3 \mathrm{H}) ; 1.2 \mathrm{~s}$ (9H). ESI-MS: $277\left(\mathrm{M}+\mathrm{H}^{+}\right)$.

$\mathrm{Cu}(\mathrm{I})$ complexes. The structures of the complexes used in this study are reported in Figure 2.

$\left[\mathrm{Cu}(\mathrm{ACN})_{4}\right] \mathrm{ClO}_{4}$. $\left[\mathrm{Cu}(\mathrm{ACN})_{4}\right] \mathrm{ClO}_{4}$ was prepared by reacting $\left[\mathrm{Cu}\left(\mathrm{H}_{2} \mathrm{O}\right)_{6}\right]\left(\mathrm{ClO}_{4}\right)_{2}$ with an excess of $\mathrm{Cu}^{0}$ powder in acetonitrile $(\mathrm{ACN})$, under stirring, at room temperature. In few hours, the color of the solution gradually turned from blue to colorless, testifying the disappearance of the $\mathrm{Cu}$ (II) starting material. The $\mathrm{Cu}(0)$ excess was removed by filtration and the transparent colorless solution was rotary evaporated to dryness to give white solid. Note that $\left[\mathrm{Cu}(\mathrm{I})(\mathrm{ACN})_{4}\right]^{+}$dismutes in presence of water traces to give back $\mathrm{Cu}(0)$ and $\mathrm{Cu}(\mathrm{II})$. As a consequence, even in the solid state, after few weeks, a chromatic variation from white to pale blue, due to the formation of $\mathrm{Cu}(\mathrm{II})$ impurities, could be observed.

General preparation of $\mathrm{Cu}(\mathrm{I})$ mediators. In order to remove eventual $\mathrm{Cu}(\mathrm{II})$ impurities, one equivalent of $\left[\mathrm{Cu}(\mathrm{ACN})_{4}\right] \mathrm{ClO}_{4}$, dissolved in $\mathrm{ACN}$, was equilibrated in presence of an excess of metallic copper powder for about 30 minutes. $\mathrm{Cu}(0)$ was eliminated by filtration and the resulting solution was slowly added, under stirring, to two equivalents of the desired ligand dissolved in acetonitrile. The color change from colorless to red-brown or purple, depending on the ligand, was instantaneous. Nevertheless, the resulting solution was allowed to sit under stirring at room temperature for about 4 hours before isolation of the desired product. Typically, the solution was evaporated to dryness, the solid residue was redissolved in the minimum amount of ACN and precipitated by addition of an excess of diethylether. The solid was collected by suction filtration, washed with ether, and dried at room temperature.

$\left[\mathrm{Cu}\left(b p y-(\mathrm{COOEt})_{2}\right)_{2}\right] \mathrm{ClO}_{4}$ (7), brown solid: ${ }^{1} \mathrm{H}$ NMR $\left(200 \mathrm{MHz}, \quad \mathrm{CD}_{3} \mathrm{OD}, \quad \delta \mathrm{ppm}\right): 9.1 \quad(\mathrm{~s}, 2 \mathrm{H}) ; 8.7 \quad(\mathrm{~s}, 2 \mathrm{H})$; $8.2(\mathrm{~s}, 2 \mathrm{H}) ; 4.5(\mathrm{q}, 4 \mathrm{H}) ; 1.45(\mathrm{t}, 6 \mathrm{H})$; anal. calcd. for $\mathrm{C}_{32} \mathrm{H}_{32} \mathrm{O}_{12} \mathrm{~N}_{4} \mathrm{ClCu}: \mathrm{C}, 50.33 ; \mathrm{H}, 4.22 ; \mathrm{N}, 7.33$. Found: C, 48.38; H, 3.67; N 7 .

$\left[\mathrm{Cu}\left(\mathrm{bpy}-(\mathrm{COOnBut})_{2}\right)_{2}\right] \mathrm{ClO}_{4}(\boldsymbol{8})$, brown solid: ${ }^{1} \mathrm{H} \mathrm{NMR}$ (200 MHz, $\left.\mathrm{CD}_{3} \mathrm{OD}, \delta \mathrm{ppm}\right)$ : $9.4-8$ (broad,12H); 4.45 


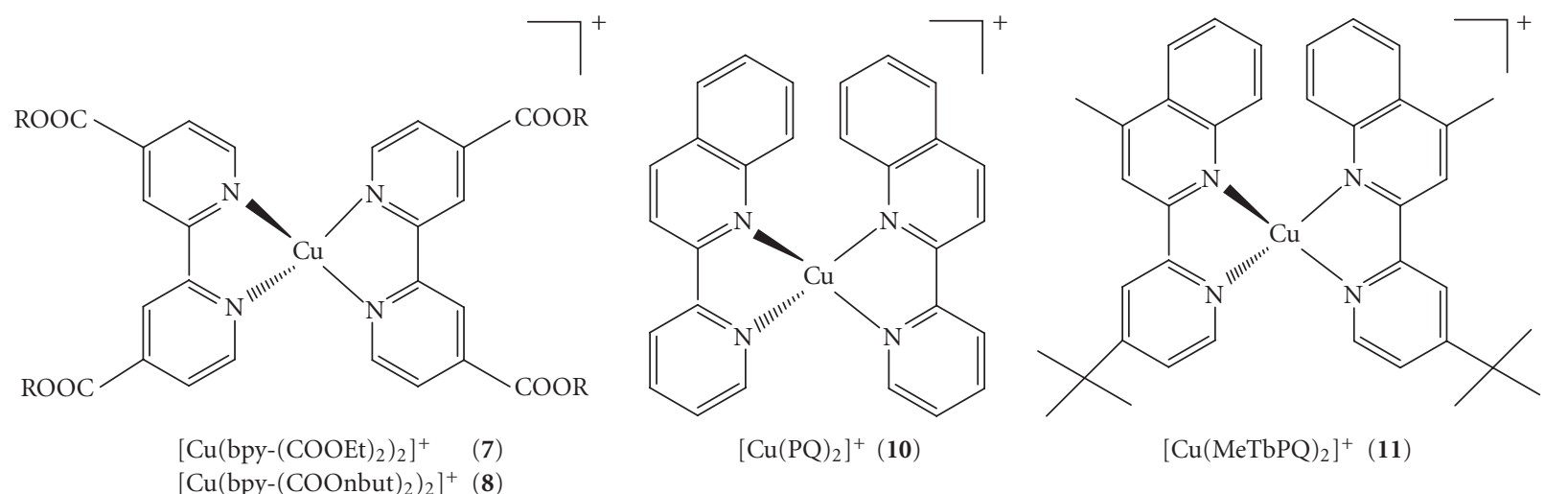
$\left[\mathrm{Cu}\left(\text { bpy- }(\mathrm{COOnbut})_{2}\right)_{2}\right]^{+}(\mathbf{8})$ $\left[\mathrm{Cu}\left(\text { bpy- }(\mathrm{COOTbut})_{2}\right)_{2}\right]^{+}(\mathbf{9})$<smiles></smiles>

Figure 2: Structure of $\mathrm{Cu}(\mathrm{I})$ complexes employed as electron transfer mediators in photoelectrochemical cells.

(m,broad,8H); 1.8 (m,broad, $8 \mathrm{H}) ; 1.5$ (m,broad,8H); 1.0 $(\mathrm{t}, 12 \mathrm{H})$; anal. calcd. for $\mathrm{C}_{40} \mathrm{H}_{48} \mathrm{O}_{12} \mathrm{~N}_{4} \mathrm{ClCu}$ : C, 54.86; $\mathrm{H}, 5.52$; N, 6.40. Found: C, 54.59; H, 5.57; N, 6.48.

$\left.\left[\mathrm{Cu}(\mathrm{bpy} \text {-(COOTbut})_{2}\right)_{2}\right] \mathrm{ClO}_{4}$ (9), brown solid: ESI-MS: $775\left(\mathrm{M}^{+}\right)$.

$\left[\mathrm{Cu}(\mathrm{PQ})_{2}\right] \mathrm{ClO}_{4}$ (10), red-brown solid: ${ }^{1} \mathrm{H}$ NMR (200 $\mathrm{MHz}, \mathrm{CD}_{3} \mathrm{OD}, \delta$ ppm): $8.8(\mathrm{~m}, 6 \mathrm{H}) ; 8.6(\mathrm{~d}, 2 \mathrm{H}) ; 8.3(\mathrm{t}, 2 \mathrm{H})$; $8.1(\mathrm{~d}, 2 \mathrm{H}) ; 7.8-7.6(\mathrm{~m}, 6 \mathrm{H}) ; 7.45(\mathrm{t}, 2 \mathrm{H})$; anal. calcd. for $\mathrm{C}_{28} \mathrm{H}_{20} \mathrm{~N}_{4} \mathrm{O}_{4} \mathrm{ClCu}$ : C, 58.44; H, 3.5; N, 9.74. Found: C, 58.01; $\mathrm{H}, 3.43 ; \mathrm{N}, 9.61$.

$\left[\mathrm{Cu}(\mathrm{MeTbPQ})_{2}\right] \mathrm{ClO}_{4}$ (11), red-brown solid: ${ }^{1} \mathrm{H}$ NMR $\left(200 \mathrm{MHz}, \mathrm{CD}_{3} \mathrm{OD}, \delta \mathrm{ppm}\right): 8.8(\mathrm{~s}, 2 \mathrm{H}) ; 8.7(\mathrm{~s}, 2 \mathrm{H}) ; 8.45$ $(\mathrm{d}, 2 \mathrm{H}) ; 8.2(\mathrm{~d}, 2 \mathrm{H}) ; 7.8(\mathrm{~d}, 2 \mathrm{H}) ; 7.7(\mathrm{~d}, 2 \mathrm{H}) ; 7.6(\mathrm{t}, 2 \mathrm{H})$; $7.45(\mathrm{t}, 2 \mathrm{H}) ; 2.9(\mathrm{~s}, 6 \mathrm{H}) ; 1.55(\mathrm{~s}, 18 \mathrm{H})$; anal. calcd. for $\mathrm{C}_{38} \mathrm{H}_{40} \mathrm{~N}_{4} \mathrm{O}_{4} \mathrm{ClCu}$ : C, 63.77; H, 5.65; N, 7.82. Found: C, 59.87; H, 5.35; N, 7.31.

$\left[\mathrm{Cu}(\mathrm{BQ})_{2}\right] \mathrm{ClO}_{4}$ (12), purple solid: ${ }^{1} \mathrm{H}$ NMR $(200 \mathrm{MHz}$, $\mathrm{CD}_{3} \mathrm{OD}, \delta$ ppm): $7.45(\mathrm{~d}, 4 \mathrm{H}) ; 7.35(\mathrm{~d}, 4 \mathrm{H}) ; 6.55(\mathrm{~d}, 4 \mathrm{H}) ; 6.2$ $(\mathrm{d}, 4 \mathrm{H}) ; 6.05(\mathrm{~m}, 4 \mathrm{H}) ; 5.85(\mathrm{~m}, 4 \mathrm{H})$.

\section{RESULTS AND DISCUSSION}

The basic electrochemical properties of the $\mathrm{Cu}(\mathrm{I})$ complexes reported in this work, investigated by cyclic voltammetry on glassy carbon electrodes, are summarized in Table 1.
Oxidation of a tetrahedral $\mathrm{Cu}(\mathrm{I})$ complex to $\mathrm{Cu}(\mathrm{II})$ involves the removal of an electron from a metal centred $\mathrm{T}_{2}$ orbital with a prevailing antibonding character. The preliminary electrochemical study showed that almost all of the $\mathrm{Cu}(\mathrm{I})$ complexes have a sufficiently negative oxidation potential to guarantee an ample driving force for reduction of most part of oxidized sensitizers. The sole exception is constituted by $\left[\mathrm{Cu}(\mathrm{BQ})_{2}\right]^{+}(12)$ which, due to the strong stabilization of metal centred orbitals induced by the augmented back bonding to four quinoline rings, exhibits an $\mathrm{E}_{1 / 2}$ only $100 \mathrm{mV}$ negative of the dye $\mathrm{Z} 907$.

In general, $\mathrm{Cu}(\mathrm{I})$ complexes give rise to slow electron transfer processes, due to the high nuclear rearrangement that accompanies the electron transfer, as shown by the peak separations which, in all cases, exceed the $60 \mathrm{mV}$ expected for an ideally reversible monoelectronic process. It is, however, clear from the data reported in Table 1 that pyridilquinoline-based complexes exhibit a markedly different electrochemical behavior with respect to the bipyridine based ones. Indeed, the former showed well-defined diffusion limited peaks, with a peak separation (without compensation of cell resistance) of the order of $100 \mathrm{mV}$, while the latter showed generally broad poorly resolved peaks with separations higher than $300 \mathrm{mV}$. Exceptionally slow is the quasireversible process associated to the oxidation of (9) with a peak separation of the order of $1.3 \mathrm{~V}$, maybe caused by the 
TABLE 1: Electrochemical properties of $\mathrm{Cu}(\mathrm{I})$ mediators in $\mathrm{ACN} / \mathrm{LiClO}_{4} 0.1 \mathrm{M}, 100 \mathrm{mV} / \mathrm{s}$.

\begin{tabular}{lcccc}
\hline Complex & $\mathrm{E}_{1 / 2}(\mathrm{mV}$ Vs SCE $)$ & Anodic Peak $(\mathrm{mV}$ Vs SCE) & Cathodic Peak (mV Vs SCE) & Peak separation (mV) \\
\hline $\mathbf{( 7 )}$ & 445 & 576 & 214 & 362 \\
$(\mathbf{8})$ & 350 & 516 & 187 & 329 \\
$(\mathbf{9})$ & 350 & 998 & -302 & 1300 \\
$(\mathbf{1 0})$ & 350 & 410 & 292 & 120 \\
$(\mathbf{1 1})$ & 280 & 342 & 226 & 120 \\
$(\mathbf{1 2})$ & 688 & 750 & 627 & 123 \\
$\mathbf{I}^{-} / \mathbf{I}_{3}{ }^{-}$ & 466 & 716 & 216 & 500 \\
$\mathbf{Z ~ 9 0 7 ~}$ & 710 & 757 & 663 & 94 \\
\hline
\end{tabular}

presence of bulky Tertbutyl-ester groups which contribute to decouple the metal centre from the electrode. As a first approximation, neglecting specific interactions with the electrodic surface (which are however possible), such, quite unexpected, difference is ostensibly related to the geometry change that accompanies the oxidation of $\mathrm{Cu}$ (I) to $\mathrm{Cu}$ (II); in case of $\mathrm{Cu}(\mathrm{I})$ pyridil-quinoline complexes, a smaller inner sphere reorganization energy probably contributes to limit the activation barrier for the electron transfer. In general, it could not be observed a dramatic dependence of the electrochemical behavior of the reported $\mathrm{Cu}(\mathrm{I})$ complexes from the electrode material, that is, similar peak shapes and separations were observed also on gold and platinum substrates. While carbon might reveal itself as an interesting and cheap cathode material, for a first preliminary study, we used gold coated counter electrodes, due to our possibility of obtaining stable and homogeneous gold layers of known thickness. On the other hand, at present, we do not possess the technology and the knowledge to create analogous stable carbon deposits with the same characteristics.

The photoaction spectra obtained with the mediators (7)-(12) are shown in Figure 3.

As can be observed from Figure 3, the best performances were obtained with mediators (11) and (7), generating an almost identical maximum IPCE\% of the order of $35 \%$, about one half of that obtained with classical $\mathrm{I}^{-} / \mathrm{I}_{3}{ }^{-}$couple. Copper-based couples (8), (9), and (10) led to lower performances with maximum IPCE varying between 30\% (10) to about 20\% (9). While the low conversion efficiencies obtained with $\left[\mathrm{Cu}(\mathrm{BQ})_{2}\right]^{+}(12)$ can be quite easily explained by the exceedingly positive oxidation potential which does not allow for an efficient dye regeneration, due to the low driving force for this process, the understanding of the different performances obtained with the other redox couples could be quite challenging. Considering that the same ruthenium sensitizer was used with all the different redox couples and the light harvesting efficiency (LHE) was always close to unity; the different IPCEs can only be explained in terms of different electron collection efficiencies $(\eta)$. At the anodic compartment of the cell, losses due to electronic recombination with the oxidized sensitizer and with acceptor states of the electrolyte (namely, $\mathrm{Cu}$ (II) centres) limit the number of electrons that are able to flow out of the cell as a photocurrent. Additionally, an inefficient $\mathrm{Cu}(\mathrm{I})$ regeneration at the counter electrode may lead to an increase of the steady concentration

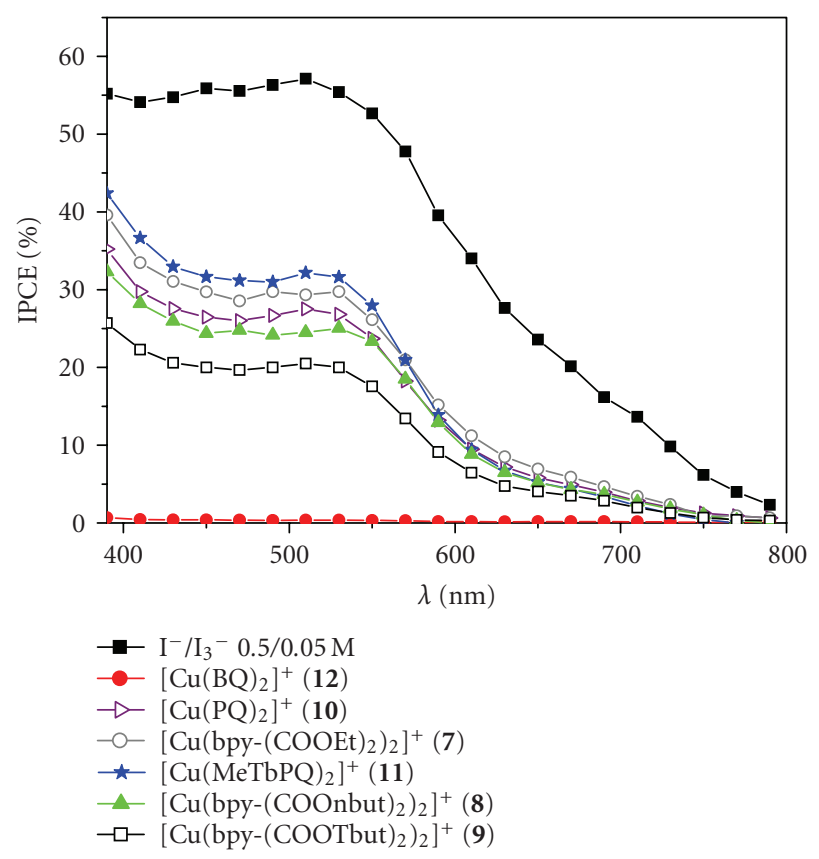

FIGURE 3: Photoaction spectra obtained in presence of $\mathrm{Cu}(\mathrm{I}) / \mathrm{Cu}(\mathrm{II})$ electron mediators using regenerative sandwich cells equipped with gold counter electrodes. (11) Stars; (7) open circles; (10) open triangles; (8) solid triangles; (9) open squares; (12) solid circles. Data were compared to the $\mathrm{I}^{-} / \mathrm{I}_{3}{ }^{-}$couple (black squares). $\mathrm{Li}^{+} 0.5 \mathrm{M}$ was added to all copper-based electrolytes.

of $\mathrm{Cu}(\mathrm{II})$, ultimately increasing the probability of photoinjected electron recapture.

First, we observe that, within the pyridil-quinoline-based $\mathrm{Cu}(\mathrm{I})$ series, the alkyl-substituted $\left[\mathrm{Cu}(\mathrm{MeTbPQ})_{2}\right]^{+}$complex allowed to obtain a maximum IPCE about 20\% higher with respect to the unsubstituted $\left[\mathrm{Cu}(\mathrm{PQ})_{2}\right]^{+}$mediator, indicating a possible beneficial effect of the alkyl chains on the mediator properties. Besides shifting the metal centred oxidation towards more negative values $(280 \mathrm{mV}$ for (11), $350 \mathrm{mV}$ for (10)), slightly increasing the driving force for dye regeneration, the presence of bulky Tert-butyl chains might partially block the back recombination, decreasing the electronic coupling between $\mathrm{Cu}$ (II) acceptors and electronically occupied $\mathrm{TiO}_{2}$ donor states. Considering the substituted bipyridine series, we clearly see that the performances 


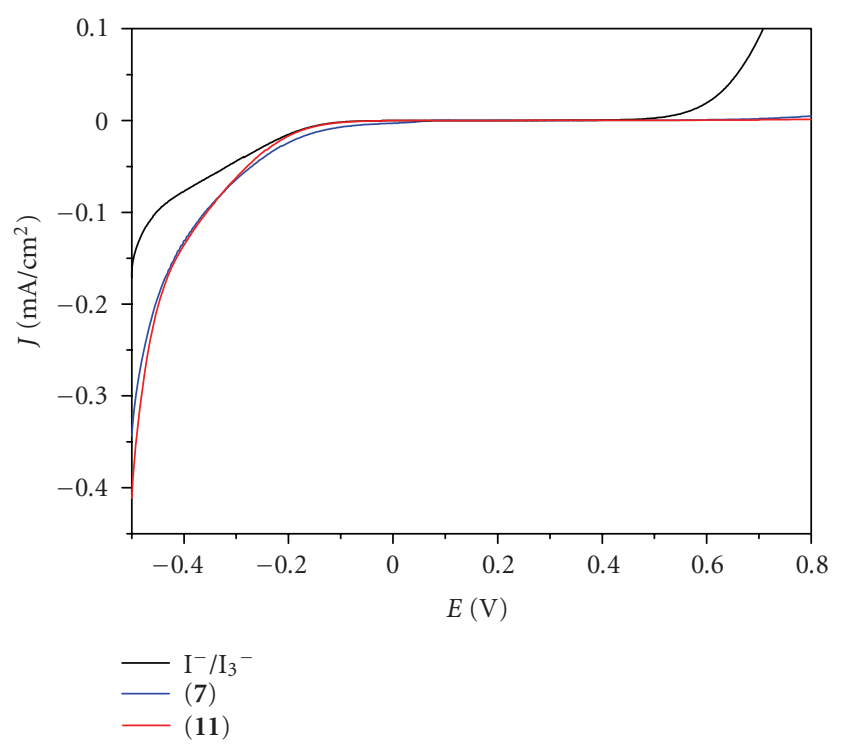

(a)

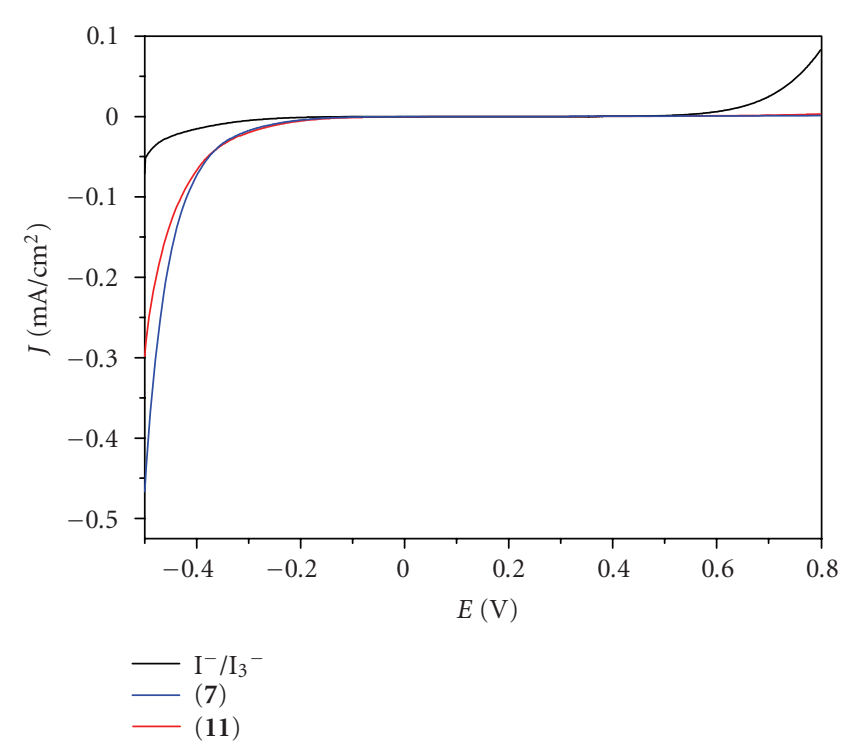

(b)

Figure 4: J-V curves obtained on $\mathrm{TiO}_{2}$ substrates in presence of $9 \times 10^{-4} / 10^{-4} \mathrm{M}$ reduced/oxidized mediators in $\mathrm{ACN} / \mathrm{LiClO}{ }_{4} 0.1 \mathrm{M}$. (a) Mesoporous $\mathrm{TiO}_{2}$; (b) Mesoporous $\mathrm{TiO}_{2}+$ compact $\mathrm{TiO}_{2}$ underlayer. Scan speed $50 \mathrm{mV} / \mathrm{s}$. Potentials are referred to SCE. The current density was calculated using the geometrical area $\left(0.5 \mathrm{~cm}^{2}\right)$ of the electrode.

decrease in the order $(\mathbf{7})>(\mathbf{8})>(\mathbf{9})$, suggesting that, in this case, the increase in steric hindrance of the ligands does not improve the overall mediator efficiency; on the contrary, it has a detrimental effect. This finding could be surprising at first; however, the electrochemical study showed that $4,4^{\prime} \mathrm{di}$ substituted bipyridine complexes are intrinsically characterized by very slow electron transfer kinetics and bulky substituents might not be able to control recombination any further. On the other hand, their presence might introduce an additional, unnecessary, barrier which may affect negatively both the regeneration of the oxidized dye and the electrochemical response of the counter electrode.

In any case, all of the investigated $\mathrm{Cu}(\mathrm{I}) /(\mathrm{II})$ couples are far from approaching the $\mathrm{I}^{-} / \mathrm{I}_{3}{ }^{-}$performances, at least in terms of IPCE\%, and a more detailed study of the two best performing mediators; namely, $\left[\mathrm{Cu}(\mathrm{MeTbPQ})_{2}\right]^{+}(\mathbf{1 1})$ and $\left[\mathrm{Cu}\left(\text { bpy- }(\mathrm{COOEt})_{2}\right)_{2}\right]^{+}(7)$ might allow us to gain some useful insights about their behavior in an operating DSSC.

The evaluation of the electrochemical response of $\mathrm{Cu}(\mathrm{I}) /(\mathrm{II})$ at a bare $\mathrm{TiO}_{2}$ surface can provide us, at least qualitatively, with an indication of the importance of charge recombination events involving the copper-based couples. In addition, since part of the recombination occurs at the exposed FTO surface, the effect of the presence of a compact $\mathrm{TiO}_{2}$ blocking underlayer can be evidenced. Figure 4 reports the $\mathrm{J}-\mathrm{V}$ curves recorded on $\mathrm{FTO} / \mathrm{TiO}_{2}$ electrodes in presence of the same concentration of $\mathrm{Cu}(\mathrm{I}) /(\mathrm{II})$ and $\mathrm{I}^{-} / \mathrm{I}_{2}$. Immediately prior to the measurement, the oxidized mediator was electrogenerated in the desired ratio in a conventional three compartments electrolytic cell by applying a constant $+1 \mathrm{~V}$ Vs SCE potential, using a large area FTO working electrode.

This experiment is basically equivalent to measuring the dark current of the cell using an uncolored photoanode, in a three-electrode arrangement. Considering Figure 4(a), it is evident that in the potential interval between 0 and $0.5 \mathrm{~V}$ versus SCE only a negligible current flowed through the cell. In case of the iodide/iodine couple (black line), an anodic current, due to $\mathrm{I}^{-}$oxidation, quickly arose as the potential approached $0.6 \mathrm{~V}$ versus SCE, while no faradic process associated to $\mathrm{Cu}(\mathrm{I})$ oxidation was observable. When the potential was scanned towards negative values, a cathodic current started to flow, due to reduction of the oxidized mediator. However, at comparable potentials, the magnitude of the current obtained in case of $\mathrm{I}^{-} / \mathrm{I}_{3}{ }^{-}$was about twice smaller than that observed in case of the $\mathrm{Cu}(\mathrm{I}) /(\mathrm{II})$ complexes, suggesting a more efficient electron capture by $\mathrm{Cu}(\mathrm{II})$ centres with respect to $\mathrm{I}_{3}^{-}$. It must be noted that (7) and (11) behaved almost identically with respect to current threshold and intensity. The presence of a compact blocking layer (Figure 4(b)) had a positive effect, leading to a negative $100 \mathrm{mV}$ shift of the cathodic current threshold and to an overall reduction of its magnitude. For example, in case of $\mathrm{Cu}(\mathrm{I})$ mediators, which, again, maintained an almost identical behavior, to a current density of about $150 \mu \mathrm{A} / \mathrm{cm}^{2}$ at $-0.4 \mathrm{~V}$ versus SCE (Figure $4(\mathrm{a})$ ), it corresponded, at the same potential, a value of less than $70 \mu \mathrm{A} / \mathrm{cm}^{2}$ (Figure 4(b)). Much smaller was, also in this case, the current associated to the $\mathrm{I}_{3}{ }^{-}$reduction. From these data, one might conclude that the lower efficiency of $\mathrm{Cu}(\mathrm{I})(/ \mathrm{II})$ complexes is related to a more efficient recombination with electron-accepting species of the electrolyte, which leads to an higher dark current. Such conclusion would not have been entirely correct. Indeed, it must be considered that the presence of a dye like $\mathrm{Z}$ 907 , with long alkyl chains designed to block recombination $[20,21]$, might significantly modify the J-V characteristics of the real operating device. Accordingly, the J-V curves of 


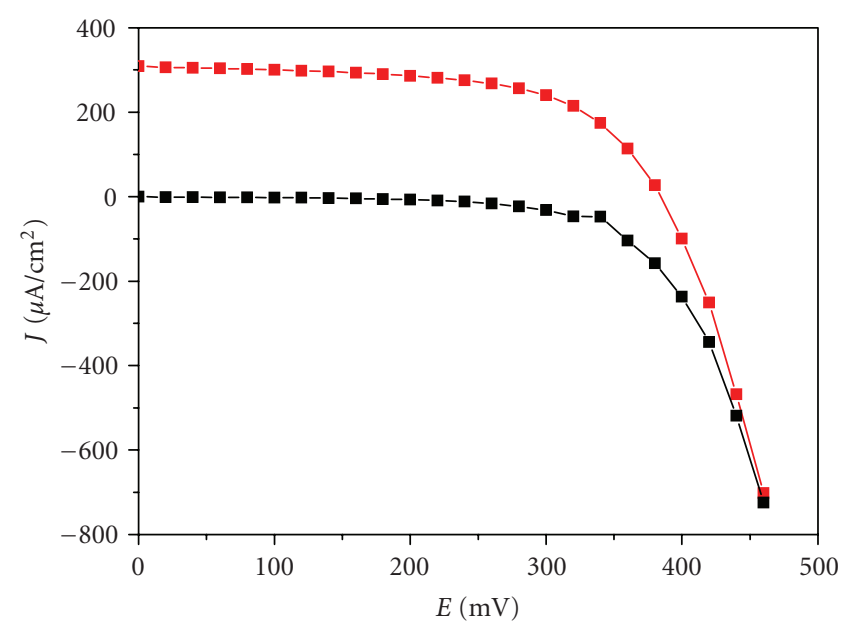

(a)

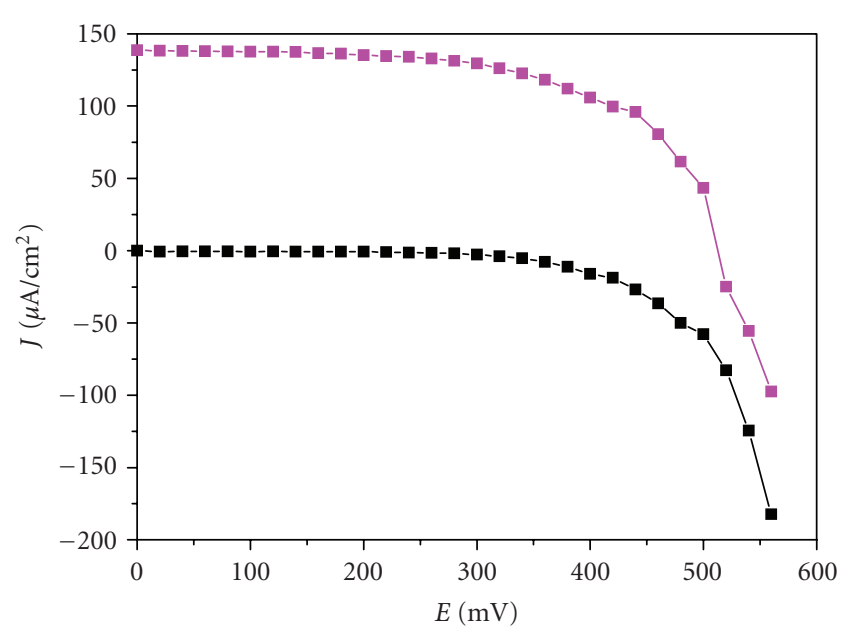

(b)

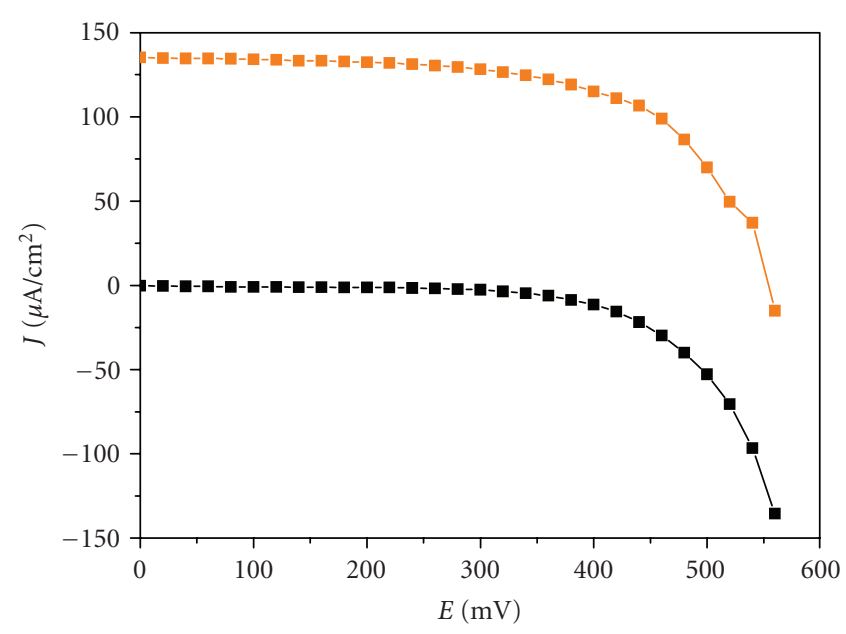

(c)

FIGURE 5: J-V characteristics of sandwich-type DSSCs recorded under $510 \mathrm{~nm}$ monochromatic light irradiation. (a) $\mathrm{LiI} / \mathrm{I}_{2}$; (b) $\left[\mathrm{Cu}\left(\text { bpy- }(\mathrm{COOEt})_{2}\right)_{2}\right]^{+/ 2+}(\mathbf{7})+0.5 \mathrm{M} \mathrm{Li}^{+} ;(\mathbf{C})\left[\mathrm{Cu}(\mathrm{MeTbPQ})_{2}\right]^{+/ 2+}$ (11) $+0.5 \mathrm{M} \mathrm{Li}^{+}$. In all figures, the black line is the cell dark current. sandwich DSSCs were recorded under monochromatic light $\left(510 \mathrm{~nm}\right.$, absorption maximum of $\mathrm{Z} 907$ loaded on $\mathrm{TiO}_{2}$ ) at low power intensity $\left(\approx 2 \times 10^{-3} \mathrm{~W} / \mathrm{cm}^{2}\right)$. We chose to investigate the photoelectrochemical behavior of our redox systems under these conditions to avoid the set in of mass transport limitations that could conceal effects determined by their intrinsically different kinetic properties. Results are reported in Figures 5(a), 5(b), and 5(c).

It is evident form the comparison of the curves in Figure 5 that the iodide/iodine couple produced the highest photocurrent, about twice that generated in presence of the copper complexes (7) and (11) which, under this point of view, showed very similar (if not identical) performances. The Voc of the $\mathrm{I}^{-} / \mathrm{I}_{3}{ }^{-}$mediated cell $(400 \mathrm{mV})$ was however ca. $150 \mathrm{mV}$ lower than the open circuit photovoltage, of about $550 \mathrm{mV}$, obtained using copper mediators. The fill factor was slightly better in case of (11), with a value of 0.63 , while in case of $\mathrm{I}^{-} / \mathrm{I}_{3}{ }^{-}$and (7) very similar values of, respectively, 0.59 and 0.57 were obtained. The blocking effect of the dye, based on the steric hindrance of the nonyl chains, is expected to be more relevant in case of bulky mediators, like $\mathrm{Cu}(\mathrm{I}) /(\mathrm{II})$ complexes, and the lower dark current that was effectively obtained in such cases confirmed our expectations. The copper mediator's higher Voc, lower dark current, and satisfactory fill factors provide a strong indication that, on a suitably designed photoanode, recombination involving $\mathrm{Cu}(\mathrm{II})$ centres is not a critical performance limiting factor with respect to $\mathrm{I}^{-} / \mathrm{I}_{3}{ }^{-}$. On the other hand, the lower Jsc generated by copper complexes might suggest a slow dye regeneration, which could be reasonably anticipated, given the slow kinetics that should be associated to the $\mathrm{Cu}(\mathrm{I}) /(\mathrm{II})$ redox chemistry.

From the photoelectrochemical study it is evident how the two structurally different complexes (7) and (11), characterized by a distinct electrochemical behavior (see Table 1) produce quite similar results when employed in a DSSC. In order to complete the electrochemical picture of these new species, the cathodic etherogeneous electron transfer processes at gold counter electrodes were investigated. In order to do so, the $\mathrm{Cu}(\mathrm{I}) /(\mathrm{II})$ electrochemical response was examined on the same substrates (gold coated FTO) used to build the regenerative solar cells. In order to gain kinetic information, a thin-layer configuration, inspired by the work of Cameron et al. [22] was adopted. Due to the close spacing between working and counter electrodes, and to the fact that the electroactive species were continuously regenerated at the counter electrode of the cell, a kinetic controlled regime was quickly established for scan speeds higher than $300 \mathrm{mV} / \mathrm{s}$, as demonstrated by the sigmoidal shape of the redox waves (Figure 6) and by the substantial independency of the peak current from the scan speed. Assuming a single step outer sphere electrochemical reaction, from the analysis of the cathodic branch of the voltammogram, by use of the high-field approximation of the Butler and Volmer equation, corrected for mass transport effects, one should obtain the equilibrium exchange current (which is a direct estimate of the heterogeneous electron transfer rate constant) and the transfer coefficient from, respectively, the intercept and the slope of the linear trait of the ln i versus overpotential $(\eta)$ curve (Figure 7 ). 


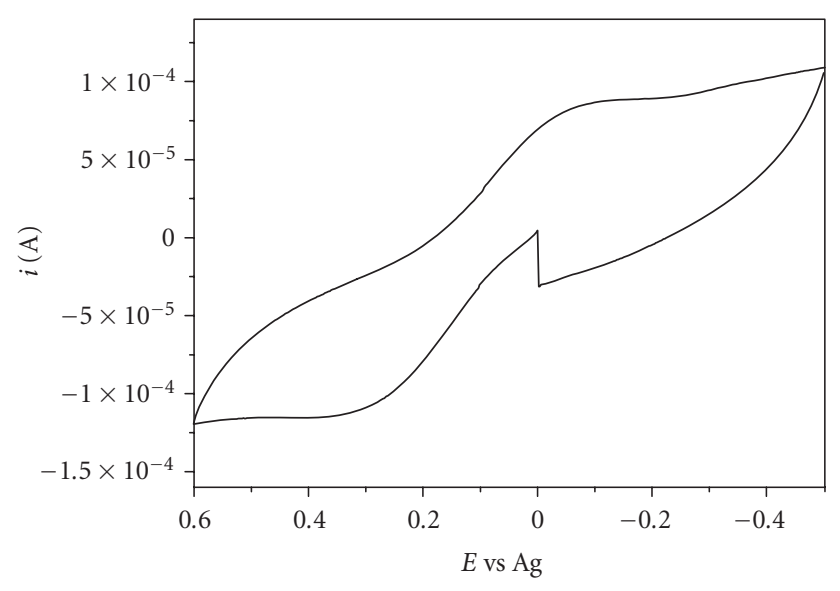

(a)

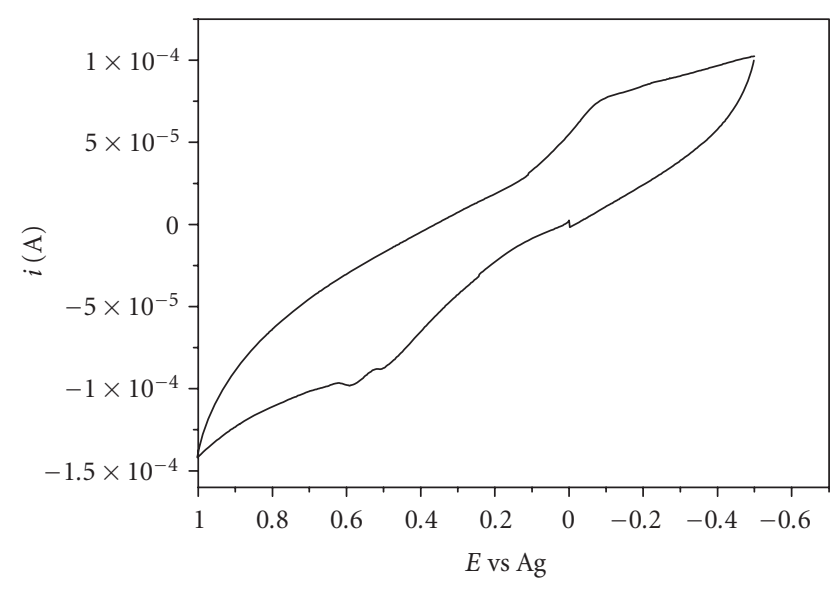

(b)

FIgure 6: Cyclic voltammograms obtained in a thin-layer electrochemical cell in presence of $5 \times 10^{-4} \mathrm{M} \mathrm{Cu}(\mathrm{I}) /(\mathrm{II}) \mathrm{in} \mathrm{ACN} / \mathrm{LiClO}{ }_{4} 0.1 \mathrm{M}$. $\mathrm{Au} / \mathrm{Au} / \mathrm{Ag}$, scan speed $700 \mathrm{mV} / \mathrm{s}$. (a) $[\mathrm{Cu}(\mathrm{MeTbPQ})]^{+/ 2+}(\mathbf{1 1})$; (b) $\left[\mathrm{Cu}\left(\mathrm{bpy}-(\mathrm{COOEt})_{2}\right)_{2}\right]^{+/ 2+}$.

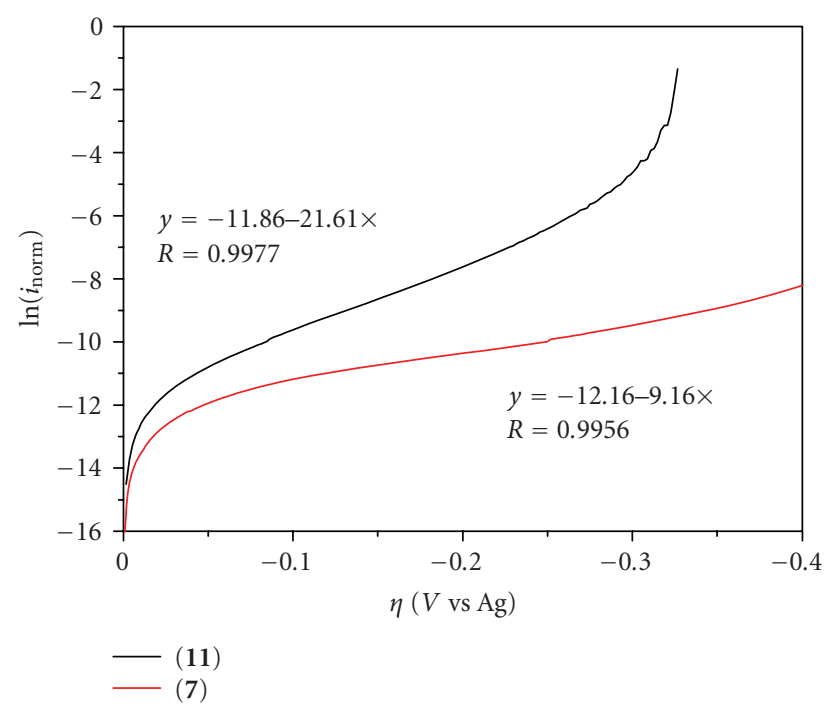

FIGURE 7: Logarithmic analysis of the cathodic branch of the cyclic volatammograms reported in Figure 6. Black line (11); red line (7). The Exchange current was evaluated from the linear fit of of the $\ln$ (current) overpotential curve. As expected, the analysis of the anodic branch led, within a good approximation, to the same result. The exchange current given in the text is the averaged value.

While the exchange currents of both complexes were found to be in the same order of magnitude, comprised between $10^{-5}$ and $10^{-6} \mathrm{~A}$, the exchange current associated to (11) was about 1.5 times larger than that generated by (7) $(7.40 \pm 0.39 \mu \mathrm{A}$ for $(\mathbf{1 1}), 4.80 \pm 0.60 \mu \mathrm{A}$ for $(7))$. The transfer coefficient of (11) was also higher, (ca 0.5 for (11), ca. 0.3 for $(7)$ ) as can be visibly appreciated from the steeper slope of its $\ln \mathrm{i}-\eta$ curve (Figrue 7, black line). These results lead us to conclude that $\left[\mathrm{Cu}(\mathrm{MeTbPQ})_{2}\right]^{+/ 2+}$ couple has better $(b u t$ not dramatically better) redox characteristics and a more satisfactory electrochemical response at the counter electrode of the cell, being potentially capable of sustaining higher current densities. This fact may partly explain the higher fill factor obtained in case of (11) - indeed, to a more facile heterogeneous electron transfer kinetic at the cathodic compartment it corresponds a decrease of the overall series resistance of the cell, finally leading to an improvement of the fill factor.

\section{CONCLUSIONS}

A series of $\mathrm{Cu}(\mathrm{I}) / \mathrm{Cu}(\mathrm{II})$ redox-couples-based on substituted bipyridines and pyridil-quinoline complexes was evaluated as electron transfer mediators in regenerative photoelectrochemical cells. The photoelectrochemical study evidenced maximum conversion efficiencies of the order of $35-40 \%$, still too low to be considered of practical interest for replacing the classical $\mathrm{I}^{-} / \mathrm{I}_{3}{ }^{-}$couple. The reasons of such low efficiencies could be explained by a slow dye reduction, leading to modest Jsc, rather than by an efficient photoinjected electron/Cu(II) recombination, since both the Voc and the fill factor obtained with copper mediated cell were higher than the corresponding $\mathrm{I}^{-} / \mathrm{I}_{3}{ }^{-}$-based DSSC. The presence of a suitably designed dye is, however, believed to be crucial for suppressing the parasitic electronic recapture by $\mathrm{Cu}(\mathrm{II}) \mathrm{ac}-$ ceptors. Future spectroscopic investigations of charge separation events involving these new mediators are expected to provide additional precise information about the electron transfer processes involving $\mathrm{Cu}(\mathrm{I}) /(\mathrm{II})$ species. The understanding of the relationship between mediator structure, redox properties, and interfacial electron transfer kinetics may allow us to rationally design new more efficient relays in the near future.

\section{ACKNOWLEDGMENT}

Financial support from EU Contract COOP-CT-2004-512510 is gratefully acknowledged. 


\section{REFERENCES}

[1] M. Gräetzel, "Solar energy conversion by dye-sensitized photovoltaic cells," Inorganic Chemistry, vol. 44, no. 20, pp. 68416851, 2005.

[2] M. S. Dresselhaus and I. L. Thomas, "Alternative Energy Technologies," Nature, vol. 414, pp. 332-337, 2001.

[3] G. Rothenberger, D. Fitzmaurice, and M. Gräetzel, "Spectroscopy of conduction band electrons in transparent metal oxide semiconductor films: optical determination of the flatband potential of colloidal titanium dioxide films," The Journal of Physical Chemistry, vol. 96, no. 14, pp. 5983-5986, 1992.

[4] J. G. Bisquert, G. Garcia-Belmonte, and F. Fabregat-Santiango, "Modelling the electric potential distribution in the dark in nanoporous semiconductor electrodes," Journal of Solid State Electrochemistry, vol. 3, no. 6, pp. 337-347, 1999.

[5] S. A. Haque, Y. Tachibana, D. R. Klug, and J. R. Durrant, "Charge recombination kinetics in dye-sensitized nanocrystalline titanium dioxide films under externally applied bias," The Journal of Physical Chemistry. B, vol. 102, no. 10, pp. 1745$1745,1998$.

[6] I. Montanari, J. Nelson, and J. R. Durrant, "Iodide electron transfer kinetics in dye-sensitized nanocrystalline $\mathrm{TiO}_{2}$ films," The Journal of Physical Chemistry. B, vol. 106, no. 47, pp. 12203-12210, 2002.

[7] B. A. Gregg, F. Pichot, S. Ferrere, and C. L. Fields, "Interfacial recombination processes in dye-sensitized solar cells and methods to passivate the interfaces," The Journal of Physical Chemistry. B, vol. 105, no. 7, pp. 1422-1429, 2001.

[8] K. Okada, H. Matsui, T. Kawashima, T. Ezure, and N. Tanabe, "100 mm $\times 100 \mathrm{~mm}$ large-sized dye sensitized solar cells," Journal of Photochemistry and Photobiology A: Chemistry, vol. 164, no. 1-3, pp. 193-198, 2004.

[9] H. Nusbaumer, J.-E. Moser, S. M. Zakeeruddin, M. K. Nazeeruddin, and M. Gräetzel, "Co ${ }^{\mathrm{II}}(\mathrm{dbbip})_{2}{ }^{2+}$ Complex rivals tri-iodide/iodide redox mediator in dye-sensitized photovoltaic cells," The Journal of Physical Chemistry. B, vol. 105, no. 43, pp. 10461-10464, 2001.

[10] S. A. Sapp, C. M. Elliott, C. Contado, S. Caramori, and C. A. Bignozzi, "Substituted polypyridine complexes of cobalt(II/III) as efficient electron-transfer mediators in dyesensitized solar cells," Journal of the American Chemical Society, vol. 124, no. 37, pp. 11215-11222, 2002.

[11] S. Itoh, N. Kishikawa, T. Suzuki, and H. D. Takagi, "Syntheses, structural analyses and redox kinetics of fourcoordinate $\left[\mathrm{CuL}_{2}\right]^{2+}$ and five-coordinate $\left[\mathrm{CuL}_{2} \text { (solvent) }\right]^{2+}$ complexes ( $\mathrm{L}=6,6$-dimethyl-2,2-bipyridine or 2,9-dimethyl1,10-phenanthroline): completely gated reduction reaction of $\left[\mathrm{Cu}(\mathrm{dmp})_{2}\right]^{2+}$ in nitromethane," Dalton Transactions, vol. 6, pp. 1066-1068, 2005.

[12] S. Hattori, Y. Wada, S. Yanagida, and S. Fukuzumi, "Blue copper model complexes with distorted tetragonal geometry acting as effective electron-transfer mediators in dye-sensitized solar cells," Journal of the American Chemical Society, vol. 127, no. 26, pp. 9648-9654, 2005.

[13] G. Sprintschnik, H. W. Sprintschnik, P. P. Kirsch, and D. G. Whitten, "Photochemical reactions in organized monolayer assemblies. 6. Preparation and photochemical reactivity of surfactant ruthenium(II) complexes in monolayer assemblies and at water-solid interfaces," Journal of the American Chemical Society, vol. 99, no. 15, pp. 4947-4954, 1977.

[14] A. R. Oki and R. J. Morgan, "An efficient preparation of 4,4'-dicarboxy-2,2'-bipyridine," Synthetic Communications, vol. 25, no. 24, pp. 4093-4097, 1995.
[15] I. Gillaizeau-Gautier, F. Odobel, M. Alebbi, et al., "Phosphonate-based bipyridine dyes for stable photovoltaic devices," Inorganic Chemistry, vol. 40, no. 23, pp. 6073-6079, 2001.

[16] C. M. Harris, S. Kokot, H. R. H. Patil, E. Sinn, and H. Wong, "High- and low-spin complexes with similar, ligands. II. Iron(II) complexes with sterically hindered analogues of 2,2'-bipyridyl," Australian Journal of Chemistry, vol. 25, no. 8, pp. 1631-1643, 1972.

[17] P. Wang, S. M. Zakeeruddin, J. E. Moser, M. K. Nazeeruddin, T. Sekiguchi, and M. Gräetzel, "A stable quasi-solid-state dyesensitized solar cell with an amphiphilic ruthenium sensitizer and polymer gel electrolyte," Nature Materials, vol. 2, pp. 402407, 2003.

[18] H. Zabri, I. Gillaizeau, C. A. Bignozzi, et al., "Synthesis and comprehensive characterizations of new cis $-\mathrm{RuL}_{2} \mathrm{X}_{2}(\mathrm{X}=$ $\mathrm{Cl}, \mathrm{CN}$, and NCS) sensitizers for nanocrystalline $\mathrm{TiO}_{2}$ solar cell using bis-phosphonated bipyridine ligands (L)," Inorganic Chemistry, vol. 42, no. 21, pp. 6656-6666, 2003.

[19] M. K. Nazeeruddin, A. Kay, I. Rodicio, et al., "Conversion of light to electricity by cis-X2bis(2,2'-bipyridyl-4,4'dicarboxylate)ruthenium(II) charge-transfer sensitizers ( $\mathrm{X}=$ $\mathrm{Cl}-, \mathrm{Br}-, \mathrm{I}-, \mathrm{CN}-$, and $\mathrm{SCN}-$ ) on nanocrystalline titanium dioxide electrodes," Journal of the American Chemical Society, vol. 115, no. 14, pp. 6382-6390, 1993.

[20] P. Wang, S. M. Zakeeruddin, P. Comte, R. Charvet, R. Humphry-Baker, and M. Gräetzel, "Enhance the performance of dye-sensitized solar cells by co-grafting amphiphilic sensitizer and hexadecylmalonic acid on $\mathrm{TiO}_{2}$ Nanocrystals," The Journal of Physical Chemistry. B, vol. 107, no. 51, pp. 1433614341, 2003.

[21] C. Klein, M. K. Nazeeruddin, D. Di Censo, P. Liska, and M. Gräetzel, "Amphiphilic ruthenium sensitizers and their applications in dye-sensitized solar cells," Inorganic Chemistry, vol. 43, no. 14, pp. 4216-4226, 2004.

[22] P. J. Cameron, L. M. Peter, S. M. Zakeeruddin, and M. Gräetzel, "Electrochemical studies of the $\mathrm{Co}(\mathrm{III}) / \mathrm{Co}(\mathrm{II})(\mathrm{dppip})_{2}$ redox couple as a mediator for dye-sensitized nanocrystalline solar cells," Coordination Chemistry Reviews, vol. 248, no. 13-14, pp. 1447-1453, 2004. 


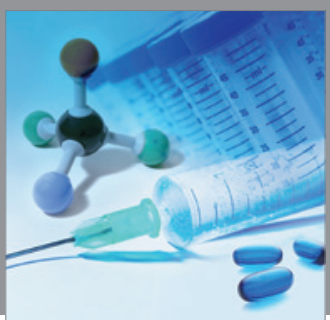

International Journal of

Medicinal Chemistry

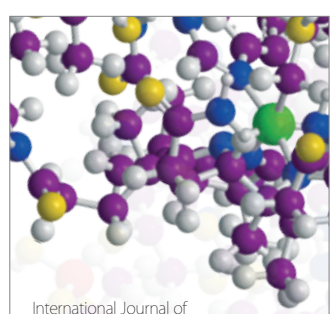

Carbohydrate Chemistry

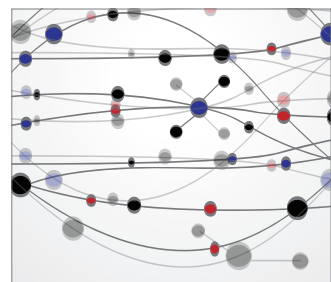

The Scientific World Journal
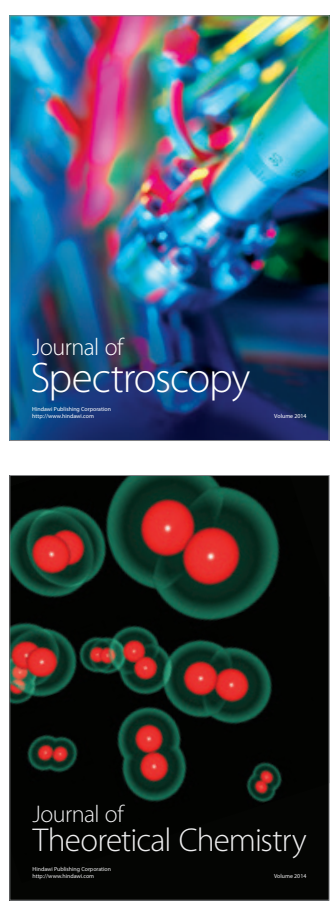
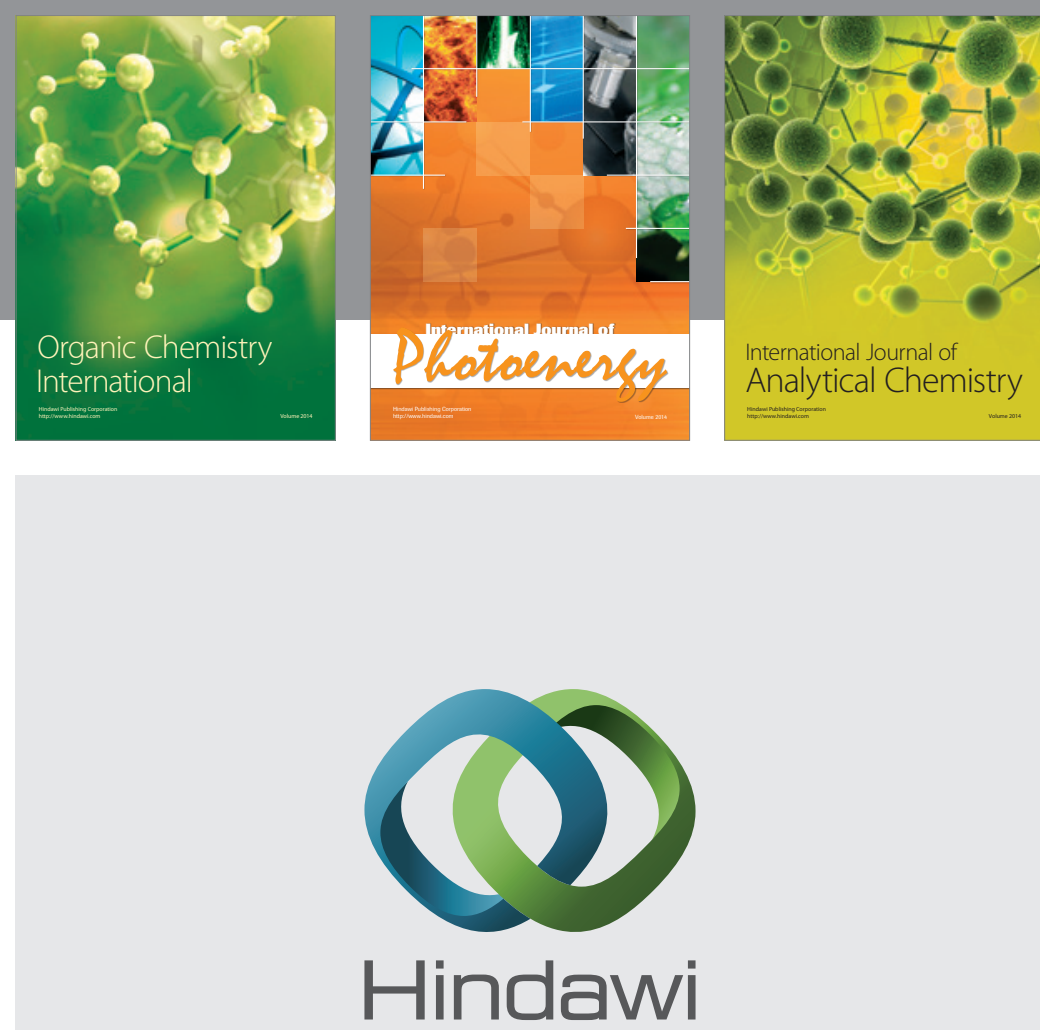

Submit your manuscripts at

http://www.hindawi.com
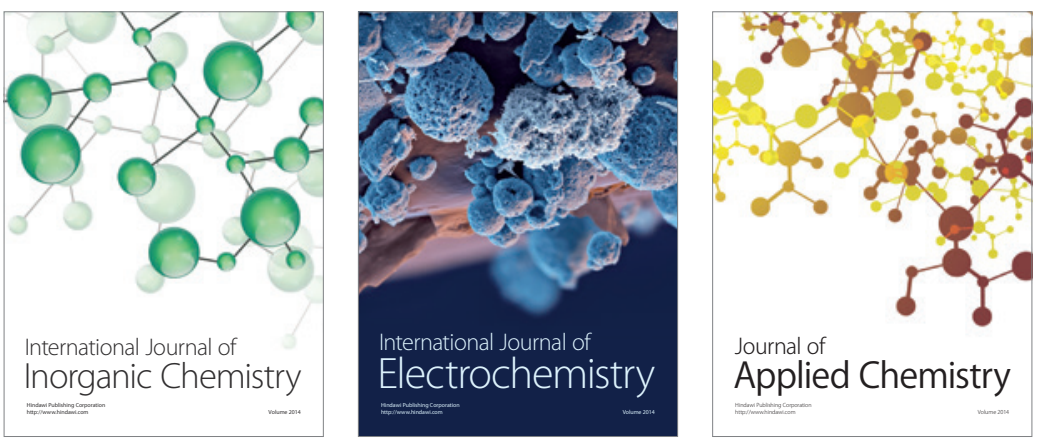

Journal of

Applied Chemistry
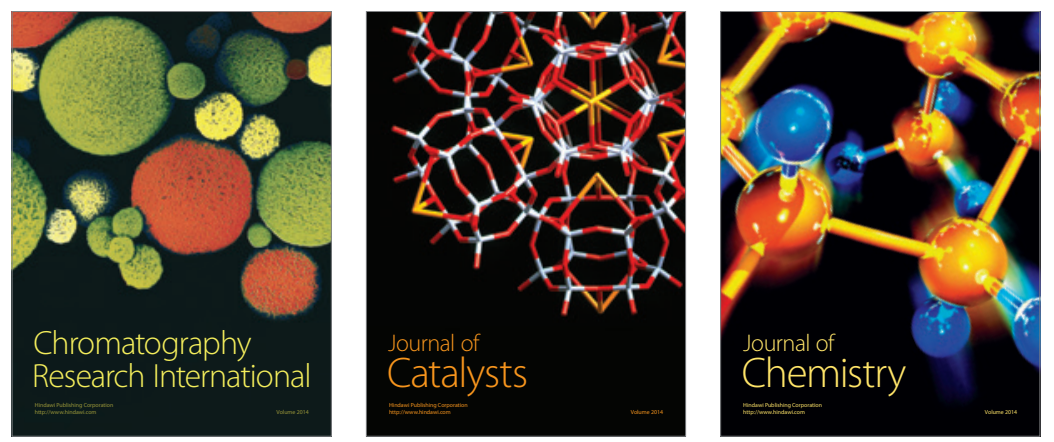
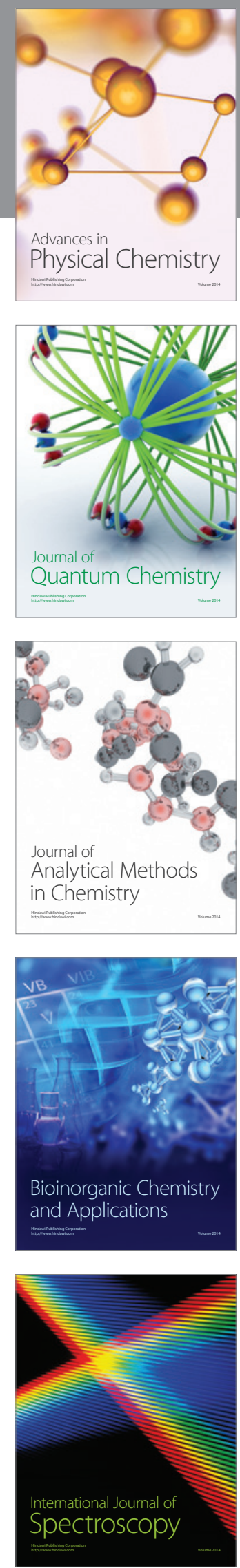